\title{
PERANAN BUDAYA ORGANISASI TERHADAP KUALITAS PENDIDIKAN
}

\section{Siti Lailatul Fajriyah}

\author{
Program Studi Manajemen Pendidikan Islam \\ Universitas Nurul Jadid Paiton Probolinggo \\ Email: fajriyahanugerah@gmail.com
}

\begin{abstract}
Abstrak: Penelitian ini ditujukan untuk mengubah peranan budaya kualitas terhadap organisasi pendidikan, dan komitmen organisasional dan menguji pengaruh budaya organisasi, Budaya organisasi didefinisikan sebagai nilai-nilai, kepercayaan dan prinsipprinsip yang berfungsi sebagai dasar system manajemen organisasi, praktek-praktek manajemen dan perilaku yang membantu memperkuat prinsip prinsip dasar tersebut (Denison,2000). Menurut Peter F Drucker dalamTika (2009) berpendapat bahwa budaya organisasi adalah pokok penyelesaian masalah-masalah eksternal dan internal yang dalam pelaksanaannya di lakukan secara konsisten oleh suatu kelompok yang kemudian di wariskan kepada anggota-anggota baru berbagai cara sebagai cara yang tepat untuk memahami, memikirkan dan merasakan terhadap masalah masalah terkait. Organisasi harus dapat mengatur dan memanfaatkan sedemikian rupa sehingga potensi sumber daya manusia yang ada di organisasi dapat dikembangkan. Pengaturan atau pengelolaan tersebut dimulai dari pengembangan pengintegrasian hingga pengaturan berkaitan dengan penggalian dan pelaksanaan budaya kerja dalam setiap fungsi dan jabatan yang ada di dalam perusahaan. Pengaturan juga berkait pemenuhan kebutuhan manusia (pemberian kompensasi) secara terus menerus dapat menghasilan peningkatan kepuasan kerja. Dari peningkatan kepusan kerja pada akhirnya menghasilkan kinerja yang baik. Namun bila karyawan dalam suatu perusahaan tidak mendapatkan pengaturan yang baik maka berpengaruh terhadap kepuasan, sehingga akibat tidak puasan maka mereka cenderung berperilaku negatif action dalam kerja seperti aksi demonstrasi, aksi mogok, dan aksi mangkir kerja dan sebagainya.
\end{abstract}

Kata kunci: kualitas budaya, komitmen organisasi, budaya organisasi. 
A. Pendahuluan

Pada umumnya kualitas adalah standar barang dan jasa yang sesuai dengan keinginan pelanggan. Menurut Juran (1991) kualitas adalah kesesuaian dengan tujuan yang meliputi perencanaan kualitas, kualitas kesesuaian and ketersediaan dan kelayakan servis.

Sementara itu Feigenbaum (1991) memandang kualitas sebagai komposit total karakteristik barang dan jasa yang meliputi pemasaran, tehnis, produksi dan pemeliharaan sehingga barang dan jasa yang dihasilkan sesuai harapan pelanggan dalam pembahasan ini penulis akan membahas Peranan Budaya Kualitas Terhadap Organisasi Pendidikan.

Meningakatkan mutu pendidikan lembaga adalah tujuan setiap lembaga pendidikan islam agar tidak stagnan dalam satu titik, yaitu, melalui melalui prosesproses yang lebih baik lagi dan lebih baik lagi. Untuk keuntungan atau mencapai tujuan bersama, yang tak lain adalah sistem dalam kepemimpinannya itu sendiri dan lembaga pendidikan tidak hanya melengkapi kebutuhan lembaga pendidikan itu sendiri melainkan juga melengkapi hal-hal yang juga dibutuhkan dari luar contohnya masyarakat setempat.

Budaya kualitas yang sering seringkali dianggap sebagai komponen kunci dari inisiatif peningkatan kualitas dalam berbagai industri, termasuk pendidikan. Banyak peneliti, bahkan hampir semuanya, setuju bahwa Total Quality mempunyai hubungan yang kuat dengan budaya organisasi (Ariani dkk, 2003) namun demikian masih terdapat perselisihan tentang isu bahwa keberadaan TQM akan berdampak pada perubahan budaya untuk mencapai kualitas menyeluruh (total quality) atau sebaliknya TQM tidak merubah budaya melainkan menggunakan budaya yang sudah ada.

Studi penjaminan mutu terutama jika dikaitkan dengan faktor budaya kualitas di Indonesia dewasa ini juga masih terbatas, Oleh karena itu menarik untuk diketahui apakah penjaminan mutu mempunyai pengaruh signifikan terhadap budaya kualitas sebagai bagian dari budaya organisasi (Kujala dan Ullrank, 2004) jika diterapkan pada institusi pendidikan di Indonesia, mengingat karakteristik budayanya yang berbeda. Artikel ini membahas tentang konsep budaya kualitas dan menempatkan konstruk sosial ini ke area Total Quality Management (TQM). Lebih jauh lagi akan dibahas tentang hubungan antara dimensi TQM dengan budaya kualitas serta penentuan unsur TQM yang memfasilitasikan praktik baik dalam pembentukan budaya kualitas institusi pendidikan. 
A. Peranan Budaya Kualitas Terhadap Organisasi Pendidikan

Budaya berkaitan dengan kebiasaan seseorang dalam melakukan sesuatu. Budaya sendiri berasal dari bahasa sansekerta dari kata dasar Budhi dan Daya yang berarti mendayagunakan akal pikiran. Jadi Budidaya berarti sebagai keseluruhan usaha rohani dan materi termasuk potensi-potensi maupun keterampilan mayarakat atau kelompok manusia. Budaya selalu bersifat sosial dalam arti penerusan tradisi kelompok manusia dari segi materialnya dialihkan secara historis dan diserap oleh generasi-generasi menurut "nilai" yang berlaku. Nilai disini adalah ukuran-ukuran yang tertinggi bagi perilaku manusia (Kepmenpan No. 25/KEP/M.PAN/04/2002).

Hal inilah yang membedakan manusia dengan makhluk ciptaan Tuhan lainnya. Selanjutnya Rita (2003) merumuskan bahwa budaya merupakan suatu pola dan mekanisme sosial yang dijalankan oleh suatu organisasi untuk mengurus anggotanya dan dapat dijadikan dasar yang tegas untuk menggerakkan anggotanya dalam melaksanakan pekerjaannya dengan baik. Budaya adalah bagaimana pola pikir kita terhadap lingkungan untuk mencapai keberhasilan seperti kecenderungan organisasi dalam berperilaku, identitas, pola hubungan yang dinamis, realitas, atau kode genetik (Schneider dalam Metri, 2005). Budaya menjalankan sejumlah fungsi didalam organisasi. Pertama budaya mempunyai peran menetapkan tapal batas; artinya budaya menciptakan pembedaan yang jelas antara satu organisasi dan yang lain. Kedua, memberikan rasa identitas ke anggota-anggota organisasi. Ketiga, budaya mempermudah timbulnya komitmen pada sesuatu yang lebih luas daripada kepentingan diri pribadi seseorang dan terakhir budaya berfungsi sebagai mekanisme pembuat makna dan mekanisme pengendali yang memandu dan membentuk sikap serta perilaku para karyawan.

Pentingnya budaya dalam mendukung keberhasilan satuan kerja menurut Newstrom dan Davis (1993) adalah budaya menjadi bagian terpenting karena dapat memberikan identitas pelaksana organisasi, budaya juga sebagai sumber stabilitas serta kontinuitas organisasi yang memberikan rasa aman bagi pelaksana organisasi dan yang lebih penting adalah budaya membantu merangsang pelaksana organisasi untuk antusias dalam tugasnya.

Dalam melakukan upaya perbaikan kualitas sangat erat hubungannya dengan budaya kualitas. Budaya mengandung berbagai aspek pokok (Bounds, 1994:101) seperti berikut: Budaya merupakan konstruksi sosial unsur-unsur budaya, seperti nilai-nilai, keyakinan dan pemahaman yang dianut oleh semua anggota kelompok; 
budaya memberikan tuntunan bagi para anggotanya dalam memahami suatu kejadian; budaya berisi kebiasaan atau tradisi; dalam suatu budaya, pola nilai-nilai, keyakinan, harapan, pemahaman dan perilaku timbul dan berkembang sepanjang waktu; budaya mengarahkan perilaku atau kebiasaan atau tradisi yang merupakan perekat yang mempersatukan organisasi dan menjamin bahwa para anggotanya berperilaku sesuai dengan norma; setiap budaya masing-masing organisasi bersifat unik.

Sedangkan budaya organisasi menurut Nasution (2005) adalah perwujudan sehari-hari dari nilai dan tradisi yang mendasari organisasi tersebut. Hal ini terlihat pada bagaimana karyawan berperilaku, harapan karyawan terhadap organisasi dan sebaliknya, serta apa yang dianggap wajar dalam hal bagaimana karyawan melaksanakan pekerjaan.

Menurut Gronros (1978) ada tiga pokok utama dalam kualitas yaitu berkaitan dengan hasil, kesan dan kriteria. Ketiga utama ini dikembagkan menjadi enam yaitu profesional dan ahli; sikap dan perilaku; akses dan fleksibel; dapat dipercayai dan amanah; solusi yang tepat; dan reputasi.

Dalam konsep manajemen kualitas modern, kualitas pendidikan tidak cukup hanya ditentukan oleh kelengkapan fasilitas atau reputasi intitusional. Kualitas adalah sesuatu standar minimum yang harus dipenuhi agar mampu memuaskan pelanggan yang menggunakan output (lulusan) dari sistem pendidikan itu, serta harus terusmenerus ditingkatkan sejalan dengan tuntutan pasar tenaga kerja yang semakin kompetitif (Gasperzs, 1997).

Unsur-unsur empiris dalam penelitaian ini diadopsi dari model budaya kualitas menurut Kujala dan Ulrank menurut Kujala dan Ullrank (2004) meliputi: pertama, misi organisasi dan hubungannya terhadap lingkungan, yang meliputi pengamatan eksternal untuk merespon kebutuhan konsumen, prioritas konsumen dalam menerapkan tujuan dan peran untuk melayani konsumen, karyawan dan lingkungan sosial. Kedua, hakekat realitas dan kebenaran, yang meliputi pengamatan internal dan ekstenal organisasi untuk mendapatkan informasi independen dan obyektif; penggunaan informasi independen dan obyektif tersebut sebagai dasar pengambilan keputusan; dan melakukan perbaikan dengan menggunakan analisis fakta yang obyektif. Ketiga, hakekat manusia dan interaksinya, yang meliputi karyawan paham akan visi dan misi organisasi karyawan mempunyai kesadaran dan motivasi kerja yang baik karyawan mampu menyesuaikan tujuan pribadinya dengan tujuan organisasi karyawan mempunyai kemandirian mengendalikan dan meningkatkan 
kualitas; kelompok kerja lebih bernilai daripada individu; karyawan berperan penting untuk mencapai efektifitas organisasi. Keempat hakekat waktu dan ruang, yang meliputi adanya kordinasi dalam merencanakn kegiatan; menetapkan bagian terkait untuk meningkatkan efektifitas organisasi; mewujudkan kualitas dalam segala aspek; membangun kemitraan sebagi bagian dari sistem dan orientasi hubungan dengan stakeholders utama dalam jangka panjang.

Pada dasarnya, budaya organisasi adalah seperangkat nilai-nilai, keyakinan, sikap dan tradisi bersama yang mengikat anggota organisasi sebagai acuan untuk bekerja dan berinteraksi antar sesama anggota organisasi.

penjaminan kualitas merupakan kegiatan untuk memberikan bukti-bukti untuk membangun kepercayaan bahwa kualitas dapat berfungsi secara efektif. Tujuan kegiataan tersebut bermanfaat,baik bagi pihak internal maupun eksternal organisasi. Tujuan penjaminan terhadap kualitas tersebut antara lain: pertama yaitu, membantu perbaikan dan peningkatan secara terus-menerus dan berkesinambungan melalui praktek yang terbaik dan mau mengadakan inovasi. Kedua, memudahkan mendapatkan bantuan, baik pinjaman uang atau fasilitas atau bantuan dari lembaga yang kuat dan dapat dipercaya. Ketiga, menyediakan informasi pada masyarakat sesuai sasaran dan waktu secara konsisten dan bila mungkin membandingkan standar yang telah dicapai dengan srandar pesaing. Keempat, yaitu menjamin tidak adanya hal-hal yang tidak dikehendaki.

Untuk mengukur kualitas sebuah lembaga pendidikan dapat dilakukan berdasarkan pengukuran kriteria Malcom Baldrige award, karena penghargaan ini merupakan standar yang dapat memicu suatu organisasi, khususnya pendidikan dalam hal pencapaiannya performansi yang tinggi serta meningkatkan kesadaran tentang pentingnya kualitas dan performansi yang baik sebagai competitif edge dengan kategori penilaiannya sebagai berikut kepemimpinan (leadership) meliputi mendefinisikan nilai, sasaran perencanaan kualitas untuk pencapain dan pengkomunikasian perencanaan strategis (strategic planing) meliputi tingkat keterlibatan pemimpin dan penyatuan rencana kualitas kedalam bisnis kepuasan pada pelanggan meliputi pesan pelanggan dalam pendefinisian kebutuhan akan kualitas pengukuran analisis dan manajemen pengetahuan (measurment, analysis, and knowledge management) meliputi dapat dipercaya (reliability), dapat disampaikan (currency) dan dapat digunakan (usability) fokus staff meliputi mengembangkan potensi kekuatan kerja secara penuh manajemen proses meliputi kualitas produk dan 
jasa hasil kinerja organisasi meliputi bagiamana perbaikan dan performansi kualitas tersebut dapat diukur. (Stephen, 1992).

Budaya organisasi mempunyai kekuatan untuk menggiring anggota ke arah pencapaian tujuan organisasi dan berpengaruh terhadap individu dan kinerjanya bahkan terhadap lingkungan kerja. Kemudian pada tataran implementasi, budaya organisasi akan diwujudkan dalam bentuk perilaku individu masing-masing anggota organisasi dalam pembelajaran mengatasi persoalan yang dihadapai.

Secara khusus kriteria penilaian Malcolm Baldridge ini mempunyai dua tujuan yang berorientasi pada hasil yaitu: menyampaikan nilai perbaikan kepada siswa dan stakeholder yang berkontribusi untuk memperbaiki kualitas pendidikan serta memperbaiki keefektifan dan kemampuan organisasi secara keseluruhan sebagai organisasi pendidikan.

Budaya organisasi merupakan sistem penyebaran kepercayaan dan nilai-nilai yang berkembang dalam suatu organisasi dan mengarahkan perilaku anggotaProsiding Seminar Nasional Peran Budaya Organisasi Terhadap Efektivitas dan Efisiensi Organisasi anggotanya. Budaya organisasi dapat menjadi instrumen keunggulan kompetitif yang utama, yaitu bila budaya organisasi mendukung strategi organisasi, dan bila budaya organisasi dapat menjawab atau mengatasi tantangan lingkungan dengan cepat (Soedjono, 2005).

Masing-masing karakteristik ini berada pada di suatu kontinum mulai dari rendah sampai tinggi. Karenanya, menilai organisasi berdasarkan ketujuh karakteristik ini akan menghasilkan suatu gambaran utuh mengenai kultur (budaya) sebuah organisasi. Gambaran ini menjadi basis bagi sikap pemahaman bersama yang dimiliki para anggota mengenai organisasi, bagaimana segala sesuatu dilakukan di dalamnya, dan cara para anggota diharapkan berperilaku.

Oleh sebab itu, budaya organisasi sangat berpengaruh terhadap perilaku para anggota organisasi karena sistem nilai dalam budaya organisasi dapat dijadikan acuan perilaku manusia dalam organisasi yang berorientasi pada pencapaian tujuan atau hasil kinerja yang ditetapkan, sehingga jika budaya organisasi baik, maka tidak mengherankan jika anggota organisasi adalah orang-orang yang baik dan berkualitas pula. Dengan demikian budaya organisasi baik secara langsung maupun tidak langsung akan berpengaruh terhadap kinerja organisasi.

Dapat disimpulkan bahwa yang dimaksud dengan budaya organisasi adalah sistem nilai organisasi yang dianut oleh anggota organisasi yang kemudian 
mempengaruhi cara bekerja dan perilaku para anggota organisasi. Dalam masyarakat budaya organisasi mempengaruhi nilai-nilai atau etika individu, sikap-sikap, asumsiasumsi dan harapan-harapan individu. Perpaduan budaya masyarakat dan budaya organisasional dapat menghasilkan dinamika di dalam suatu organisasi. 


\section{B. Kesimpulan}

Berdasarkan hasil penelitian dan pembahasan dapat disimpulkan sebagai berikut: Diketahui bahwa budaya kualitas, di pengaruhi oleh kepemimpinan, perencanaan strtegis, fokus pada pelanggan, pengukuran, analisis dan manajemen pengetahuan, fokus staff, manajemen proses, dan hasil kinerja organisasi. Maka berarti peningkatan terhadap variabel kepemimpinan, perencanaan strategis, fokus pada pelanggan, pengukuran, analisis dan manajemen pengetahuan, fokus staff, manajemen proses, dan hasil kinerja organisasi akan meningkatkan budaya kualitas. Sehingga hipotesis pertama yang menyatakan dimensi TQM memberikan pengaruh positif terhadap budaya kualitas diterima. Berdasarkan uji elastisitas variabel kepemimpinan mempunyai pengaruh dominan terhadap budaya kualitas.

Dalam pelayanannya, karyawan lebih mengutamakan kepuasan bagi siswa dan wali murid sehingga terjalin keharmonisan antara karyawan dengan para stakeholder untuk meningkatkan kualitas pendidikan sekolah, sebaiknya karyawan diberikan pelatihan-pelatihan yang dapat meningkatkan self efficacy agar tidak tergerus ditengah perkembangan zaman serta dalam perencanaan strateginya harus mengarah pada pencapaian visi dan misi serta berfokus pada kebutuhan pelajar dan stakeholder. Pimpinan lebih proaktif dalam mensosialisasikan visi dan misi lembaga kepada para karyawan melalui berbagai cara, misalnya dengan penempelan slogan-slogan yang engarah pada pencapaian visi dan misi. Setiap institusi pendidikan perlu melakukan benchmark dengan industri yang sejenis. 


\section{DAFTAR RUJUKAN}

Baharun Hasan, Manajemen Mutu Pendidikan, (Tulungagung: Akademi Pustaka, 2017).

Rifa'I Moh, Community Emprowerment In Islamic boarding school, (Kraksaan, CV. Mandiri, 2017).

Nasution, M.N., (2005). Manajemen Mutu Terpadu. Ghalia Indonesia: Bogor.

Ariani, Dorothea Wahyu. 2003. Manajemen Kualitas Pendekatan sisi Kualitatif.

Ghalia Indonesia. Yogyakarta.

Mundiri, A. (2012). PENDIDIKAN TEKNOHUMANISTIK BERBASIS CORE ETHICAL VALUES. At-Tajdid, $1(1), 37-47$.

Mundiri, A. (2015). KOMITMEN ORGANISASIONAL SUMBER DAYA MANUSIA DALAM MENINGKATKAN MUTU PENDIDIKAN PESANTREN. Pedagogik, 3(1), 88-105.

Mundiri, A. (2016). THE LEADERSHIP OF HEADMASTER IN BUILDING A WORK CULTURE

BASED ON PESANTREN. In International Conference on Education and Training (pp. 1-7).

Malang: Faculty of Education State University of Malang. 